\title{
Examination Malpractice: Causes, Effects and Possible Ways of Curbing the Menace. A Study of Cross River University of Technology
}

\author{
Oko, Sylvanus Ushie Ph.D; F,cfia \\ Department of Accountancy \\ Faculty of Management Sciences \\ Cross River University of Technology \\ oksylushies@gmail.com \\ Adie, Roseline Ishanga \\ Faculty of Law, University of Jos \\ rossysharon@yahoo.com
}

\begin{abstract}
The moral issues in the society and the quest for certificate in the face of poor academic performance has been identified as some of the major causes of examination malpractices in Nigeria. This paper reviewed the remote causes, the various types and forms of examination malpractice especially at the university level, its effects and possible ways of curbing the menace. The research findings revealed an array of factors responsible for examination malpractice in Nigeria to includes what most respondents called "wrong value system which leads to serious quest for certification instead of knowledge and skills”, Laziness, lack of preparation or in-adequate preparation for examination, lack of self confidence, poor school facilities, (Lack of or in-adequate examination hall) poor sitting arrangement, socio-economic factors, political- undertone, privatization and commercialization of education, poor invigilation, weak parental function e.t.c. Attitudinal or value change from certificate acquisition to knowledge acquisition, reduction in student population per invigilator, building of examination halls to accommodate sizeable number of students with wire net windows to forestall free flow of material to and fro the examination halls and a general change in societal value system and attitude in the educational system were advocated and recommended as measures to curve examination malpractice.
\end{abstract}

\section{EXAMinAtion}

The oxford advanced learners dictionary (2000) defined examination as spoken or practical test at school or college especially an important one that you need to do in order to get a qualification. The Wikipedia further asserted that a test or examination is an assessment intended to measure a testtakers knowledge or skill, aptitude, physical fitness or classification in many other topics (e.g. beliefs). A test may be administered orally, on a paper, on a computer or in confirmed area that requires a test taker to physically perform a set of skills. Examination is an organized assessment technique which presents individuals with a series of questions or tasks geared towards ascertaining the individual acquired knowledge and skills (Oduwaiye, 2014).

\section{Examination MalpRaCtice}

Examination malpractice is defined as any deliberate act of wrong doing, contrary to the rules of examinations designed to give a candidate an undue advantage. Examination malpractice also known as cheating is the illegal action that students take during their examinations to try to make good grades by cutting corners. Examination malpractice is an act or irregular manner of testing candidates which contravenes the rules and conventions guiding the conduct of examinations. Examination malpractice has done a lot of harm to students since many of them have neglected their books with the hope of performing the magic they are used to in every examination. Examination malpractice in Nigerian educational system has been widely discussed and viewed as a major challenge not only to examination bodies but to school administrators, the entire education system, the government and the society at large. Examination malpractice as defined by West African Examination Council (WAEC) (2003) is any irregular behaviour or act exhibited by candidates or anybody charged with the 
responsibility of conducting examination in or outside the examination hall, before, during or after such examination with the aim of taking undue advantage. Many of these irregularities or misconducts surround examination and it came to an alarming rate in the last three decades.

The hues and cries about examination malpractice taking place at all levels of the Nigerian educational system is nothing but a reflection of the decay in the value system of the society. The Nigerian society is that which celebrates mediocrity and views cheating as being smart. The society does not want to know how an individual achieves success. The important thing is the success. In fact in Nigeria the end justifies the means instead of the means justifying the end. In actual fact examination malpractice is a variant of the wrongs and corruption in the society. The politicians employ rigging at elections and enjoy enviable political offices and so do students cheat from primary to tertiary institutions to move from one level of education to another. All sorts of misconducts take place in and around examination venues to take undue advantage of the process and achieve "success". To make matter worse it is not only students that are involved, Business centres inside or around schools, parents, teachers, school heads, and examination officers all collude with students to perpetrate this misconduct. For Example, It is common during Joint Admission and Matriculation Board (JAMB) examination, to see up to 5000 persons in examination centre that has 500 candidates. The other persons who are not writing the examination come around to crowd the venue as aids to those writing the examination. The collusion between two or more of these agents makes it more difficult to combat. Even the penalties stipulated in Act 33 of 1999 constitution ranging from cancellation of results to 21 years jail- term has failed to achieve any significant shift from the cheating culture due to the effect of collusion (Ijaiya, 2004; Oduwaiye, 2014).

The university system evaluates the achievement of students' learning by administering two major types of examinations. Each course is evaluated by continuous assessment test (C.A. Test) and semester examination. These two types of examination are not spared of malpractices or irregularities of one type or the other. It is the intention of this researcher to find out the remote causes of examination malpractices, the types or forms of malpractices and recommend measures aim at stopping or reducing the ugly trend. (Onyechere, 2004; Olanipekun, 2013 and Adewale 2014).

\section{Forms OF EXAMination MALPRACTICE}

The following are some identified forms of examinations malpractice:-

Leakage: This means that the content of examination or part of it is disclosed prior to taking the examination. Usually it involves one or more of the following: staff members of the examination authorities, printers, proof readers, and messengers.

Impersonation: An individual who is not registered as a candidate for a particular examination takes the place of one that is registered. Usually this involves collusion between the chief examiner and the examination supervisor. It frequently involves tertiary institutions students taking the test for monetary reward or a favour for a girl friend or boy friend.

Smuggling of Foreign Materials: This is perhaps the most common form of malpractice. It relates to the introduction of unauthorized materials (e.g. parts or whole note books, text books, micro chips and answers) into the examination hall. Foreign materials are frequently smuggled in pants, shoes, hems and bras or deposited or fixed in the hall prior to the examination or even smuggled in by the candidates or their aids during the examination.

Copying: Copying from another candidate's work with or without permission.

Collusion: Unauthorized passing of information between candidates usually by exchanging notes or scripts. This is usually facilitated by inadequate spacing between desks and laxed supervision.

Makers Malpractice: Deliberate alteration of marks designed to inflate or deflate a candidate's original mark. This can be initiated by examination officials or candidates (Eze, 2012 \& Olanipekun, 2013)

\section{Causes of Examination Malpractice}

The idea that, in Nigerian, certificate is most important than the skills to deliver is what prompted most students into malpractice so as to have the required certificate to be there. The society regards possession of certificate as Alfa and Omega where an individual is only recognized if he possesses certain certificate. Other factors responsible for examination malpractice in Nigeria includes what 
Examination Malpractice: Causes, Effects and Possible Ways of Curbing the Menace. A Study of Cross River University of Technology

most respondents called "wrong value system which leads to serious quest for certification instead of knowledge and skills", Laziness, lack of preparation or in-adequate preparation for examination, lack of self confidence, poor school facilities, (Lack of or in-adequate examination hall) poor sitting arrangement, socio-economic factors, political-undertone, privatization and commercialization of education, poor invigilation, weak parental function. e.t.c. (Onyechere 2004; Awambor, 2004)

\section{Purpose of Study}

Considering the magnitude and the continuous occurrence of examination malpractice in the Nigerian educational system including the ivory tower, it is no doubt necessary to research into this area before the Nigerian certificates become worthless pieces of paper. The educational system needs to join the anti-corruption crusade to rid the system of this plague.

The study therefore critically examined the various forms of examination malpractices and the causes of examination malpractice in Nigerian universities, using Cross River University of Technology as a case study and recommended possible ways of curbing the ugly trend.

Requirements for Taking Examination in CRUTECH: Proper Conduct and misconduct

In order to appreciate what constitute exam malpractice and in its effort to curb the ugly trend the Cross River University of Technology (CRUTECH) management clearly enumerates in the students' handbook the following as requirements to be admitted into the university examination hall, what constitute proper conduct and misconduct during examination.

\subsection{Requirements for Taking Examination in CRUTECH}

To be admitted into the University examination hall, the candidate must:

- Have duly registered for the course

- Satisfied $75 \%$ attendance at lectures

- Follow the approved course of study for a prescribed period

- Pay all fees prescribed by senate as and when due

- Comply by any additional requirements approved by senate

\subsection{Proper Conduct during Examination}

- Students shall be at the examination hall at least 30 minutes to the advertised time for the examination

- Students must produce their registration and identity cards to every examination and leave them conspicuously displayed on the desk for the inspection of the invigilators throughout the examination

- Students shall write their registration numbers not names clearly at the appropriate place on the cover of the answer booklet and separate sheet(s) attached to the answer booklet.

- No student shall be allowed to leave the examination room during the first hour of the examination except on emergency. In such emergency cases, the invigilator shall must complete the appropriate form and refer such student to the medical centre. The script must be retrieved from the candidate before leaving the examination hall.

\subsection{Misconduct During Examination}

- Obstructing any invigilator/ supervisor in the performance of his/her duties, thereby causing harm or damage.

- Impersonation: writing an examination for another candidate/student

- Falsification of test or examination marks/grade

- Destroying evidence by chewing or any other means or an attempt to do same

- Use of scripts other than those designated for an examination 
- Bringing to examination hall unauthorised materials relevant to the examination being taken

- Copying with co-operation

- Copying without co-operation 'giraffing'

- Presentation of identical responses/answers to the same question(s) by two or more students even in cancellation

- All forms of communication during examination e.g passing or dropping papers and collecting or picking papers

- Appearance of different handwriting in a student's script

- Courier: Smuggling of examination question paper or material from or to examination hall.

- Reading of notes or text books in the toilet or outside during the relevant examination

- Mobile phones and data or information storage devices shall not be taken to or allowed in examination halls.

\section{Methodology}

The population of this study covers students and other stakeholders of Cross River University of Technology. The study sample consists of 250 respondents who includes; 150 undergraduates, 50 graduates of Cross River University of Technology and 50 parents/ guardians who were randomly selected to complete questionnaires on causes, types, and possible ways of curbing examination malpractice. The instrument used to collect data was constructed by the researcher and was face validated by another lecturer in Accountancy department with reliability co-efficient of 0.90 . There were three parts; A, B and C consisting of seven questions each. Section A requires the respondents to rank the different forms of examination malpractices according to their frequency of occurrence while section B sought to identify factors responsible for examination malpractice. Section C solicits respondents view on factors that can eradicate or reduce the ugly trend of examination malpractice.

\section{DISCUSSION OF FINDINGS}

The research findings revealed various forms and styles of examination malpractices including but not limited to; impersonation, disorderliness, cheating, giraffing, conspiracy and aiding, forging of results, machinery, microchips, smuggling of question papers out of examination venues, smuggling answer scripts into examination venues, sorting and rewriting

The study also identified various tricks employed by students to cheat during examinations and found the following features manifesting frequently in answer scripts. Some of them are similar answers, the same mistakes, exceptionally neat or rough answer scripts as if written outside, out of range answer scripts, some scripts containing more than one hand writings, using of different ink or biros in between work, forgetting microchips in answer booklets, providing verbatim answers as contained in marking scheme e.t.c

The study revealed an array of factors responsible for examination malpractice in Nigeria which includes: wrong value system, quest for certification instead of knowledge and skills, Laziness, lack of preparation or in-adequate preparation for examination, lack of self confidence, poor school facilities, (Lack of or in-adequate examination hall) poor sitting arrangement, socio-economic factors, political- undertone, poor invigilation, weak parental function. e.t.c.

Factors identified as reasons why examination malpractices has not been eliminated or reduced are among others, the fact that, the penalties as stipulated in Act 33 of 1999 constitution has not been fully applied. Some respondents however felt strongly that, just as jail term or public execution has not been able to deter armed robbers in Nigeria, a jail term as stipulated in the Act may not stop examination malpractice hence the advocated for the cut off of the link that exists among the perpetrators of examination malpractice. Act 33 of 1999 Constitution stipulates cancellation of results, fines as much as N100, 000.00 to a jail term of up to 21 years. The Act however remains a toothless bulldog. Cross River University of Technology stipulates a number of penalties such as rustication for academic session to expulsion to serve as deterrent to students. 
$70 \%$ of the respondents agreed that copying other candidates' scripts through spying also known as 'giraffing' was the most commonly used form of examination malpractice. To forestall that, they said, 'invigilators most times changed or shuffled the sitting arrangement of students who copy or allow their work to be copied'.

Collusion with other students was ranked second by $65 \%$ of the respondents. This goes along with the first as many students who giraffe had earlier formed a syndicate of sitting arrangement whereby a brilliant student sits in the middle while those who need assistance sit on the either side with chains of other dependents clustering around the machinery.

The study also revealed that there is electronic cheating (e-cheating). This occurs through the use of mobile phone and other data or information storage devices for examination malpractice. This could assume the form of electronic mails, SMS from syndicates, online browsing in examination hall as well as retrieval of stored data which could be typed data or snapped pages of text books or note books which are retrieved from the storage devices like cell phones, BB, IPAD, IPHONE etc in the examination halls. This was ranked third by $60 \%$ of the respondents.

Bringing into the examination halls prepared answers in form of microchips and prepared answer scripts was equally identified as a form of examination malpractice by $55 \%$ of the respondents.

Sorting is another form of examination malpractice identified by the study. Respondents identified a common slogan among students, 'read to know and sort to pass'. The study revealed that most students who are certificate driven resort to sort and pass instead of reading to know since their aim is just to acquire certificate.

Leakage of question from the point of preparing questions was identified as another form of examination malpractice.

Impersonation was identified as another form of examination malpractice still in practice despite the stiff penalty as contained in Act 33 of 1999 constitution. The respondents revealed that most a times brilliant students who passed their examination hide in the crowd in pretence that they failed and are repeating the course just to impersonate and write for their colleagues who failed. This they do for a fee.

Students' collusion with invigilators who sometimes are staff, students and non staff brought in by lecturers to assist and supervise examination was equally identified as another cause of examination malpractice.

From the analysis above, it is apparent that the major causes of examination malpractice are: misplaced priority for certificate acquisition against knowledge and skill acquisition due to the certificate syndrome in the society, Lack of preparation and inadequate preparation by students. The situation is so bad that if any university converts its matriculation ceremony to a convocation ceremony, with the view of awarding degree certificates to the matriculating students, many if not all will happily rise to collect the certificate and thereafter organise thanksgiving service and party. Students do not prepare for exams with the belief that they will find short cut. After all economists say that 'nobody will want to work except motivated with reward or threatened with punishment'. However there is no short cut to success as the only sure way to success is hard work. 'Perspiration in preparation is inspiration in presentation' (PIPIIIP.

Another factor that students identified as a cause of examination malpractice is that there are many distractions in the university that are non- academic. The observation of the respondents is that majority of students spend more time on activities that are non-academic such as: politics, socials, religious activities, travelling e.t.c. These activities take them away from lectures and most times from continuous assessments then when they find out that the semester has run out, they begin to look for how to cut corners.

\section{EFFECTS OF EXAMination MALPRACTICE}

The consequences of examination malpractice both to education and the society will be catastrophic in the long run candidates/students who would ordinarily be working hard to pass examination will now depend on quack arrangements since they believe so much in such arrangements that it rarely failed. Then the fraud or malpractice may eventually be seen as a way of academic exercise. The 
candidates produced in this manner will grow into adults and teachers or examinations officials who will not see anything wrong with such sophisticated and high class examination fraud thus defeating the goals of education by turning out certificated illiterates. Examination malpractice increases lack of confidence among students. Students who would have ordinarily passed an examination feel disappointed and lose confidence when less intelligent ones perform better than them through cheating, thus leading to loss of confidence in themselves and in the examination and the system at large. Examinations malpractice may lure some students into other areas of misconducts such as prostitutions and or armed robbery, female students who lack money to sort or pay for scores may take prostitution while male may as well take stealing or armed robbery in a bid to make money to pay for scores (Onyechere, 2004; Adewale, 2014 \& Uzochukwu, 2015)

Other general effects of examinations malpractice can be summarized as follows:

- The products of examinations malpractice are square pegs in round holes. They lack the required knowledge and experience to carry out their assignment and professional duties effectively.

- Examinations malpractice produces candidates with low morale and academic values. The products of examination malpractice always end up with unfulfilled dreams in their chosen career.

- Examinations malpractice is a negative orientation for future leaders who may end up being fraudulent and corrupt in their various offices.

- Anyone who engages in examinations malpractice is building on a false foundation which can lead to serious professional errors.

\section{CONClusion}

Examination malpractice take place in all forms of examinations and it is almost a routine to cheat in these examinations. Everyone continues to decry this cankerworm in the Nigerian education system and all penalties put in place to stop it remains almost ineffective if not totally ineffective.

The causes could be attributed to societal value system, the behaviour of candidates, parents and the education system. The consequences could be catastrophic to both education system and the society as it would turn out the society certificated illiterates. The respondents identified different forms of examination malpractices including but not limited to; impersonation, disorderliness, cheating, giraffing, conspiracy and aiding, forging of results, machinery, microchips, smuggling of question papers out of examination venues, smuggling answer scripts into examination venues, sorting and rewriting.

They traced the factors responsible for examination malpractice to, and blamed students as not being adequately prepared for examination, other stakeholders in the educational system as tolerating and supporting it and the society at large for being responsible for the continuous rise in examination malpractice.

Students preferred light penalties such as cancellation of examination and rustication for academic session as against stiffer punishment like imprisonment and expulsion from the university as contained in the laws of the land.

\section{RECOMMENDATIONS}

Based on the research findings, the following recommendations were made to curb examination malpractice.

- Change in value system, the situation where people place so much value on certificate does not augur well for our academics as it encourages examination malpractice. Sound educational policy should be put in place with de-emphasis on the supremacy of certificates over skills and professional competence.

- Students who engage in examination malpractice have been found to be academically weak. The weakness could be traced to faulty foundation in their educational ladder. It is therefore recommended that they should be improvement in the delivery of instruction especially at the foundation i.e primary and secondary levels.

- The universities should guide against indiscriminate admission of students so as not to overstretch the available facilities. The National Universities Commission (NUC) is waging war against 
over-crowding in universities. Universities should ensure they admit only qualified students and this should be based on available facilities as stipulated by NUC.

- The Federal and State Government should continue to establish more universities to give opportunities to more candidates seeking admission in order not to over stretch facilities in existing universities. Considering the teeming population and the number of JAMBITES who meet the cut off point every year, we recommend that every senatorial district should have a public university.

- The ban on the use of mobile cell phones, BBs and IPAD in examination halls should be enforced to check the new wave of e-cheating.

- The integrity of the university lecturer is important in curbing examination malpractice. Lecturers and supervisors should be persons of proven integrity. The invigilators should be very vigilant in the supervision of examination and should be fair to all. The question of double standard should not arise.

- Stakeholders should stop paying leap services to Examination malpractice. Religious and community leaders should be used to intervene on parents who insist on their children getting the best result without genuine efforts for it.

- The rigidity and timing of examinations should be reviewed in such a way that when a student complains genuinely that he cannot write an examination another time suitable should be organized for him, may be, in form of summer exams, this will eliminate the phobia of failure which may result in impersonation and other form of malpractices.

\section{REFERENCES}

Act 33 of the 1999 Constitution of the Federal Republic of Nigeria as Amended.

Adewale, G. (2014). Examination Malpractice: A Stigma on School Effectiveness in Nigeria. Https://www.unilorin.edu.ng

Awambor, M (2004). Examination Malpractice and our future as a nation. www:techinceptions.com

Eze, H. (2012). Examination Malpractice in Nigeria. www: nigeriaworld.com/articles/2012 Cross River University of Technology Students' Handbook 2014.

Calabar Ijaiya, M. N (2004) Checking Examination Malpractice in Nigerian Schools. www://research-education-edu.blogspot.com. July 13, 2009

National Universities Commission Benchmark Minimum Academic Standards 2011 www.academia. edu

Oduwaiye, R. O.(2014) Students' Perception of Factors and Solution to Examination Malpractices in Nigerian Universities: A case study of the University of Ilorin. www.academia.edu

Olanipekun, O. 2013; Trends in Examination Malpractice in Nigerian Educational System. www:ajhss.org.

Onyechere, J. (2004). Consequences of Examination Malpractice. www.ajol.info/index Oxford advanced learners dictionary (2000)

Uzoccukwu, Mike. (2015) Examination Malpractice and Causes. http://uzochukwumike.Hubpages. com June 16, 2015

West African Examination Council (WAEC) Publication on Examination Malpractice (2003). www://naija.com.

\section{AUTHOR's BIOGRAPHY}

Dr. Sylvanus Ushie, OK0 is a lecturer with the Department of Accountancy, Faculty of Management Sciences, Cross River University of Technology (crutech), Cross River State, Nigeria. Dr. S. U. OK0 has served as examination Officer for many years and is presently the sub Dean of the faculty and campus. 